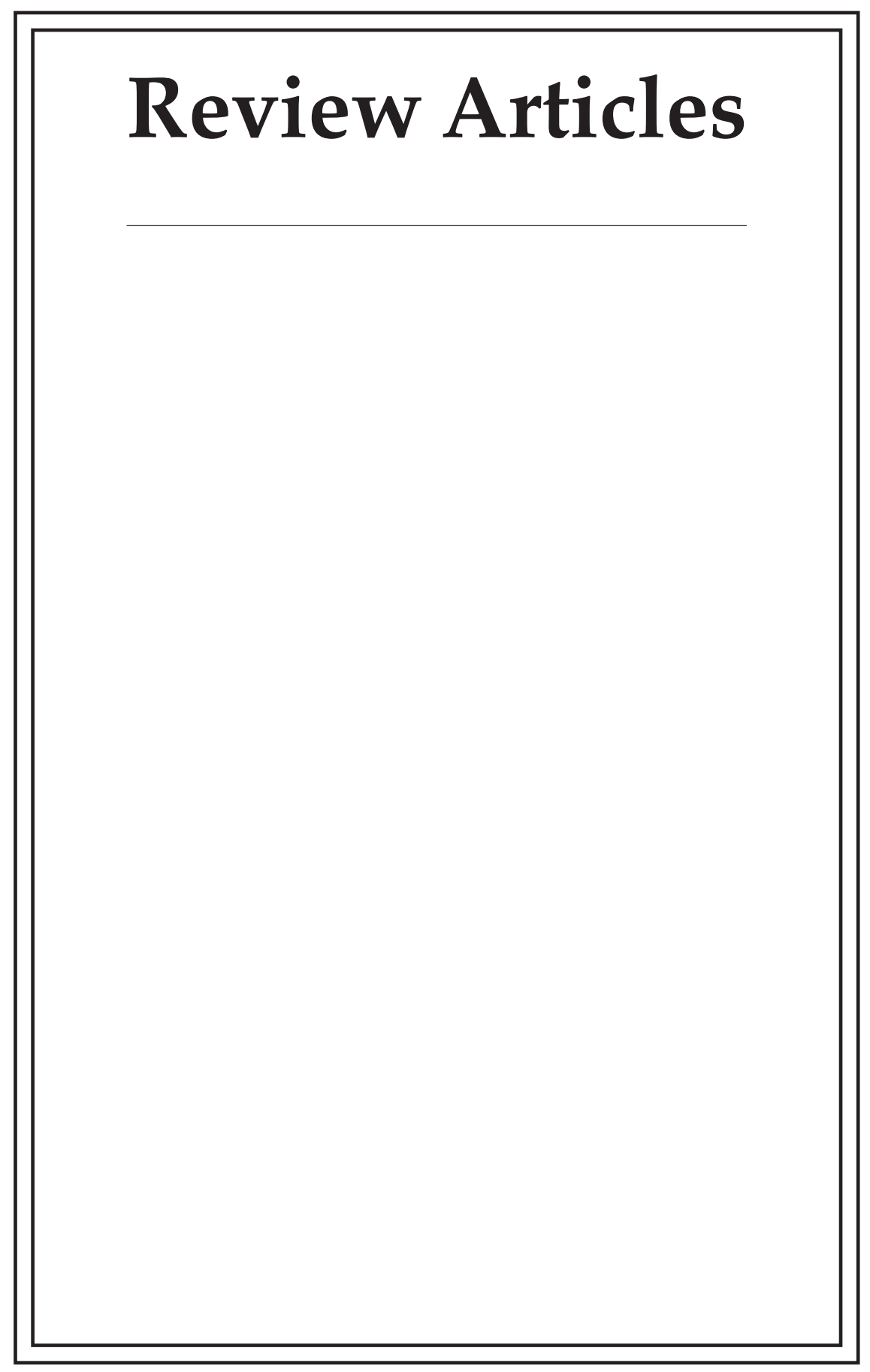

Downloaded from Brill.comఠ4/26/2023 01:23:34PM 
Dmitry Biriukov

Saint Petersburg State University of Aerospace Instrumentation

University of Padova

Saint Petersburg, Russia

dbirjuk@gmail.com

\section{PROVIDENCE AND FATE IN THE ANCIENT PHILOSOPHICAL TRADITION AND IN GREEK PATRISTICS}

Григорий БЕНЕвИч, Краткая история «промысла»

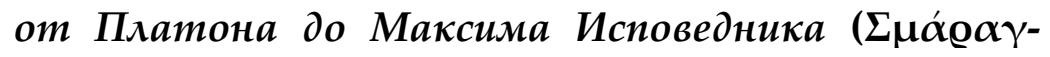

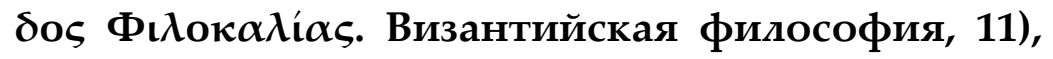
Санкт-Петербург: Русская Христианская гуманитарная академия, 2013, 315 с. ISBN 978-5-88812-654-7 [Grigory BENEVICH, A Brief History of Providence

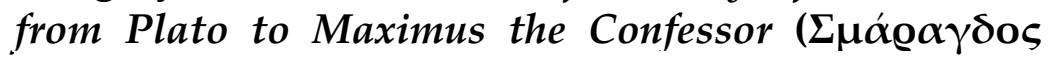
Фı入ок $\alpha \lambda i ́ \alpha \varsigma$. Byzantine Philosophy, 11), Saint Petersburg: Russian Christian Academy for the Humanities, 2013, 315 p.]

This book provides an overview of the themes of providence ( $\pi$ @óvot $\alpha$ ) and fate $(\varepsilon \dot{\varepsilon} \mu \alpha \varrho \mu \varepsilon \dot{v} \eta \eta)$ in the ancient philosophical tradition and in Greek patristics. It can immediately be seen that the title of the book is slightly narrower than its content, since, as the author himself points out, the main theme of his research is the "relationship between providence and fate" (p. 103) in the philosophers and theologians under study, i. e. the work is devoted not only to the notion of providence but also to the notion of fate. Despite the fact that, as Gregory Benevitch shows, the theme of providence/fate was relevant for ancient and patristic philosophers in terms of both human and physical (natural) reality, the author focuses on human reality alone.

Benevitch's main idea is very interesting and quite original and it seems that it has never before been explored despite its relative simplicity. This idea is to trace back how concepts relating to the providence and fate, were developed in the doctrines of significant thinkers from Ancient paganism through to Byzantine Christianity. Fur- 
thermore, this book is "Maximus-centric," as the author has chosen Maximus the Confessor's doctrine of providence as the point of convergence ${ }^{1}$ for the different lines of through which he outlines. We can also note that the research includes certain larger-scale themes which cut through the chapters, such as the relationship between providence/fate and the general and individual, the status of astrology and the status of free will etc.

At the beginning of his book, Benevitch lists some "classic issues on providence." He counts twelve such issues. Within these, he marks out the issues which are the most significant for his study and which fall within the book's main field of attention. He focuses in particular on the "understanding of providence and fate by various philosophical schools (and by some of the key authors in such study), as well as the problem of the correlation of providence and fate in the teachings of these schools and in certain philosophers" (p. 18).

In his exposition of the historical development of the concepts of providence and fate Benevitch begins with the teaching of Socrates (as reported by Xenophon) on two aspects of the topic of providence: firstly "physics," and secondly the concern of the gods in lives of people. Both of these aspects continued to be important throughout the subsequent thinkers which he considers (p. 21).

During his exposition of Plato, Benevitch notes that alongside the idea (associated with the goodness of the Demiurge) that providence extends to the cosmos, Plato also includes the notion that fate extends to souls coupled with bodies. This emphasis led, in the Platonic tradition, to the development of two conceptions of providence the second of which was subordinated to the first one. Another key point in Plato's teaching was that the very soul of man became responsible for its fate, whereas the mythological tradition assumed that the lot of a person depended on Moiraes (p. 24). As concerns notions of the general and the individual, for Plato, providence did extend to the individual, however he gave greater preference to providence on the general level (p. 25).

Benevitch draws attention to the way in which concepts of fate and providence coincide in Stoic teaching. In Stoic doctrine, providence/fate were capable of producing particular attitudes to misery

(1) The author himself says that Maximus' teaching is the "horizon for his research" (p. 12), but the metaphor of "horizon" is not quite clear for me in this respect. 
and hardship. For the Stoics a "fate adopted stoically is the meeting point of a man with God" (p. 30). Benevitch compares the Platonic and Stoic views, noting that, in contrast to the Stoics, Plato maintains the independence of human freedom from fate (p. 33).

Considering Middle Platonism, Benevitch notes the influence of the hierarchisation of the Divine sphere on doctrine of providence, in particular through the appearance of a distinction between types and levels of providence. Thus, the Supreme God's providence did not extend to the subcelestial world; this lead to the idea of a hierarchically lower fate carried out by daemons. Benevitch shows that, in Middle Platonism, ideas of punishment were rationalized, being understood as an atonement for derogation from the laws of fate. Thus, whilst the ideas of Middle Platonism did not imply a desire to withdraw from the world of fate, later Platonic as well as Gnostic teachings proceed from a desire to leave this world.

Turning to Philo of Alexandria, Benevitch notes the importance of his emphasis on the divine providence in history, where God leads his people and the world towards a particular goal (p. 42). Alexander of Aphrodisias contributes an Aristotelian stream due to his opposition to determinism in nature and his provision of a place for accident within it. In response to the Platonists' criticism that in Aristotle providence extended only to the realm of heaven, Alexander developed teaching on the relation between celestial bodies and the subcelestial region. This doctrine, implying the existence of levels of providence, brings together Alexander with Middle Platonic doctrines (pp. 46-47). At the same time, Alexander did not go so far as to admit that providence may also care for individuals and this, according to Alexander, allowed individuals freedom from determinism. However, unlike Alexander, Christian apologists who lived at approximately the same time claimed that divine providence extended to the individual and not just to the general (pp. 46-49, 53-57, 60-61).

Among the early Christian writers Clement of Alexandria deserves a specific mention as his teaching about the synergy between the saints and divine providence had an impact on subsequent Christian tradition including, probably, Maximus the Confessor (p. 61). Clement also developed ideas surrounding the correlation between providence and the Logos which cares for everything and for every smallest part of existence. Here Clement acts as a forerunner of "logology" and its connection with the doctrine of providence in Dionysius the Areopagite and Maximus the Confessor (p. 62). 
Origen is interesting on account of his concept of the "heavenly book," an alternative to pagan astrological fatalism. Disputing the correspondence of fate to the location of stars, Origen argued that nevertheless the location is not accidental and can be perceived qua signs. As Benevitch writes, "this concept to varying degrees was assumed by many Christian writers, although we cannot consider it to be a generally accepted church doctrine" (pp. 66-67). Here we may note a certain vagueness on the part of the author since later, discussing the relationship between astrology and Ancient Christian teaching, Benevitch writes that, in the framework of Ancient Christian doctrine as a whole, stars did not affect the circumstances of a human life (p. 129). An important aspect of Origen's teachings consists in the idea that God, having foreknowledge of the future, does not predetermine it. Later, this doctrine was taken up, in his own way, by Maximus the Confessor (pp. 68-71). Finally, Origen influenced the development of ideas of logoi of providence and judgment in subsequent Christian tradition (p. 76).

With regard to Plotinus, Benevitch shows that, while he integrated various aspects of Plato, Aristotle, Stoics, and Middle Platonists into his own doctrine, at the same time he introduced new elements. Plotinus suggested the possibility of withdrawal from the power of fate through a focus on the true and highest soul, of overcoming the passional part of the soul, and of the achievement of independence of soul from sensory impressions. According to Plotinus, providence is

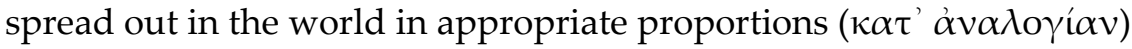
to all its parts. Afterwards, this idea played an important role in Proclus, Dionysius and Maximus (pp. 86-87).

The specificity of Iamblichus' understanding of providence/fate is associated with his rejection of the Plotinian idea that the true soul dwells in the divine sphere and is independent of the body. While Plotinus proceeded from the assumption of the need to leave behind the passional part of soul that lives according to the laws of fate, Iamblichus aspired to develop a positive approach and thus his doctrine involved a positive use of the laws of fate.

Discussing Hierocles, Benevitch notes that he (in a similar manner to John Chrysostom) put forward the doctrine of God's two providential wills: the prior will that "those who sin would not die," and the posterior will that "those who have fallen into evil, would finally die." Later this topic was also developed by John of Damascus (p. 98). Benevitch demonstrates that the distinctive feature of Proclus' teach- 
ing on providence consists in his elevation of providence to the level of the One that made the sphere of providence prior to the realm of the ideas. Like his Platonic predecessors, Proclus distinguished the spheres of activity of providence and fate; the distinction between the two spheres corresponding to that between the intelligent and corporeal natures. In contrast with Hierocles, for whom fate was understood primarily in relation to its ethical dimension, Proclus' understanding was framed according to onto-cosmological terms, as something relating primarily to the cosmic whole (pp. 114-122).

Of the Christian authors prior to Maximus the Confessor, Benevitch touches on Nemesius of Emesa, Evagrius, and Dionysius the Areopagite. He analyzes the polemics between Nemesius and Middle Platonic philosophers on whether the result of our actions depends on fate. Benevitch relates the specifics of Nemesius' position in particular to Christian guidelines regarding communication with God and prayer which offer connection with God without the need for mediation by the laws of fate. Disagreeing with a layered understanding of providence and fate, Nemesius refused to distinguish between the two. According to him, one and the same God extended his providence to all created beings, including individuals, and God did not entrust the functions of providential care for the subcelestial region to any daemon or celestial body. It is worth noting that Nemesius does not offer a clear answer to the question of the relationship between providence and what depends on us (p. 146). Later, Maximus the Confessor and John Damascene would suggest their own solutions to this issue.

Benevitch analyzes Evagrius' doctrine relating to logoi of providence and judgment later to be revised by Maximus the Confessor. He also deals with the doctrine of Dionysius the Areopagite, noting that, unlike Proclus, whom Dionysius is based largely upon, Dionysius did not use the concept of fate, but instead allows providence to became all-embracing so as to include all actions of the Godhead in relation to created beings.

Finally, Benevitch analyzes Maximus the Confessor's teaching on providence in the context of his logoi theory, his Christology, his ecclesiology, his soteriology, and his anthropology. Maximus borrowed from Nemesius his definition of providence the rationale for its existence, as well as concept of the relation between providence and the individual. At the same time, in contrast with Nemesius, Maximus went so far as to specify the relationship between providence and 
what depends on us. Maximus also reworked Evagrius's doctrine on logoi, providence and judgment; he considered providence not so much in moral as in onto-dynamical terms, qua referring not only to human reality but to all things (pp. 173-175). Benevitch considers the Dionysian impact on Maximus' concept of judgment, while discussing differences between the approaches of Dionysius and Maximus in this regard. Benevitch shows that, unlike his pagan predecessors, Maximus did not consider God's judgment and justice as "lower" levels of deity. In Maximus, both divine providence and judgment belonged to the One God, as his forces directed towards creation.

Thus, Maximus transformed the ancient doctrines of providence and fate into doctrines of divine providence and judgment. His approach presupposes an understanding of providence and judgment in terms of onto-dynamics, in which judgment, taking part of the role of fate in pagan philosophical thought, acquired ontological significance. This understanding, implying the equivalence and "simultaneity" of divine providence and judgment, competes with the doctrine of the two wills of God which is found in John Chrysostom, Hierocles, John of Damascus, and several later authors (e. g. Thomas Aquinas and Gennadius Scholarius) (pp. 220-221).

While the title of the book states that it is dedicated to the history of providence up until Maximus the Confessor, the final chapter contains the author's observations on the subject of providence in John of Damascus and in late Byzantine literature. ${ }^{2}$ In the chapter on John of Damascus Benevitch in particular criticizes the conclusions of the lengthy article by John Demetrakopoulos on theodicy in the Dama-

(2) I might here note that in the section on late Byzantine literature Benevitch mentions the topic of providence in the controversy between Gregory Palamas and Nicephorus Gregoras and therefore refers to the commentaries written by both me and Dmitry Makarov which have been published in the book: Д. БИРЮКОВ и Д. МАКАРОВ, “Комментарии," in: Георгий Факрасис, Диспут свт. Григория Паламы с Григорой философом. Философские и богословские аспекты паламитских споров, пер. с древнегреч. Д. А. ПОСПЕЛОвА, отв. ред. Д. С. БИРЮКОв [D. BIRIUKOV and D. MAKAROV, "Commentaries," in: Georgy Fakrasis, Disputation of St Gregory Palamas with Nicephorus Gregoras, a Philosopher. Philosophical and Theological Aspects of the Palamite controversy, trans. D. POSPELOV, ed. D. BIRIUKOV], Москва, Святая гора Афон, 2009, с. 87; and doing it, he confuses authorship and attributes my commentary to Makarov (p. 216, n. 864). 
scene. ${ }^{3}$ Namely, unlike Demetrakopoulos, who considers the doctrines of Ammonius son of Hermias and Stephan of Athena in particular to be important sources for the Damascene's teaching on divine predestination and predetermination, Benevitch sees no need to take into account these authors in this context, pointing instead to the teachings of Maximus the Confessor and of Origen (p. 201, n. 825).

This brief overview has shown that Gregory Benevitch's book is a supremely meaningful, informative and conceptual study. Two shortcomings are worth mentioning in conclusion, firstly the omission of early Christian writers between Origen and Nemesius (e. g. the Cappadocian fathers are given very little consideration, and Athanasius of Alexandria is not mentioned at all), and secondly the lack of discussion surrounding the relationship between concepts of providence and theodicy in the considered authors (this topic is briefly outlined by the author, but it does not get a satisfactory treatment in the book - apparently because the topic of theodicy is absent in the doctrine of Maximus the Confessor whose teaching is one of the key anchor points for the converging lines traced by the author).

(3) Unfortunately, the publication information for this paper has been left out of the bibliographic section of the book. Benevitch meant the following article by Demetrakopoulos: "In Search of the Pagan and Christian Sources of John of Damascus' Theodicy," in Byzantine theology and its philosophical background, ed. by A. RIGO in coll. with P. ERMILOV and M. TRIZIO, Brepols, 2011, pp. 50-86. 